\title{
c-Met antisense oligodeoxynucleotides increase sensitivity of human glioma cells to paclitaxel
}

\author{
SHENG-HUA CHU, YAN-BIN MA, DONG-FU FENG, HONG ZHANG, JIAN-HUA QIU and ZHI-AN ZHU \\ Department of Neurosurgery, No.3 People's Hospital Affiliated to Shanghai Jiao Tong University \\ School of Medicine, Shanghai 201900, P.R. China
}

Received January 18, 2010; Accepted April 6, 2010

DOI: $10.3892 /$ or_00000845

\begin{abstract}
Cell culture, tissue chemistry and flow cytometry were used to determine whether antisense c-Met oligodeoxynucleotides enhanced the sensitivity of human glioma cells to paclitaxel. A combination of paclitaxel with antisense c-Met oligodeoxynucleotides inhibited cell growth, induced apoptosis and induced c-Met protein expression in U251 and SHG44 human glioma cells more significantly than either paclitaxel or the oligodeoxynucleotides on their own $(\mathrm{P}<0.01)$. Thus, c-Met antisense oligodeoxynucleotides increase the sensitivity of human glioma cells to paclitaxel. Combined use of the two agents could be a novel and attractive strategy in human glioma treatment.
\end{abstract}

\section{Introduction}

Paclitaxel is FDA-approved for clinical use in ovarian and breast cancer $(1,2)$. It has shown cytotoxic activity against common solid tumors and a number of leukemias, Walker 256 carcinosarcomas and lung tumors (3). Paclitaxel is a potent inhibitor of cell replication that works by blocking cells in the late $\mathrm{G} 2$ or M phase of the cell cycle and binding to cellular microtubules for promoting the polymerization of microtubules $(4,5)$. However, there were two main problems in the applications of paclitaxel. One is supply and the other is formulation. The problem of supply has been resolved by means of semisynthetic approaches based on the taxane skeleton, which is widely available from more abundant relatives of the Pacific Yew. More recently, developments in plant biotechnology have enabled the use of plant tissue culture to produce relatively large amounts of paclitaxel in a controlled bioreactor, thus protecting the environment by reducing the need to cut down more trees (6). The problem of formulating paclitaxel, however, still remains a large obstacle

Correspondence to: Dr Sheng-Hua Chu, Department of Neurosurgery, No.3 People's Hospital Affiliated to Shanghai Jiao Tong University School of Medicine, Shanghai 201900, P.R. China E-mail: shenghuachu@126.com

Key words: antisense oligonucleotide, apoptosis, c-Met, glioma, paclitaxel because of the widespread use of the drug. Paclitaxel is currently administered in a vehicle formulation composed of 1:1 blend of Cremophor EL (polyethoxylated castor oil) and ethanol, which is diluted with 5- to 20-fold in normal saline or dextrose solution (5\%) for administration. This formulation is stable in unopened vials for 5 years at $4{ }^{\circ} \mathrm{C}$. However, there are many problems employing this vehicle (7). This is mainly because Cremophor EL has a number of associated side effects including hypersensitivity reactions, nephrotoxicity, neurotoxicity and cardiotoxicity. Use of this drug might be made safer and more efficient, and its therapeutic effects might be enhanced, by an agent that acts synergistically with it.

We have previously found $\mathrm{HGF} / \mathrm{c}-\mathrm{Met}$ played an important role in the formation and progression of the brain astrocytoma and could promote tumor proliferation and intratumoral microvascular formation, and was closely related to the prognosis of the patients (8-13). We have also found that recombinant human hepatocyte growth factor could resist apoptosis of U251 glioma cells induced by mitomycin $C$, and the sensitivity of U251 glioma cells to mitomycin C could be enhanced by the blockage of the c-Met mRNA $(14,15)$. Previously, we showed that antisense oligodeoxynucleotide targeting the c-Met gene also down-regulated or inhibited cMet expression, which inhibited U251 glioma cells growth and induced cell apoptosis (9). Thus, c-Met antisense sequences might have the desired synergistic effect with paclitaxel on glioma cells. In this study, we explored this possibility using U251 and SHG44 glioma cells.

\section{Materials and methods}

Cell culture and measurement of HGF levels. U251 (human glioma cells, from Wuhan University of China, Wuhan) and SHG44 cells (human glioma cells, from Fourth Military Medical University of China, Xi'an) were incubated at $37^{\circ} \mathrm{C}$ in RPMI-1640 medium supplemented with $10 \%$ calf serum, $100 \mu \mathrm{g} / \mathrm{ml}$ penicillin and $100 \mu \mathrm{g} / \mathrm{ml}$ streptomycin, in an atmosphere of $5 \% \mathrm{CO}_{2}$ at saturation humidity. The cell lines were sub-cultured 2-3 days later with an initial concentration of $5 \times 10^{4}$ cells $/ \mathrm{ml}$. Cells in logarithmic growth were used in all experiments. The cells were plated in 6 -well plates at $25 \%$ confluence and allowed to attach overnight. Conditioned medium was collected $0,24,48,72$ or $96 \mathrm{~h}$ and the number of cells in each well was determined using a hemocytometer. 
Debris was pelleted for $5 \mathrm{~min}$ at $2000 \mathrm{rpm}$ and supernatant was collected and stored at $-20^{\circ} \mathrm{C}$. A dilution series sequence of the samples with the highest and lowest expected values of HGF was first performed to determine the appropriate dilutions. Hepatocyte growth factor levels were measured via ELISA using an ELISA kit (Biosource International, Camarillo, CA) according to manufacturer's guidelines and normalized to cell number in each well. Levels of HGF were expressed in $\mathrm{pg} / \mathrm{ml}$ per $10^{6}$ cells. From the cumulative measured values, the HGF secretions by day were calculated. All samples were performed in duplicate. All experiments were done in triplicate.

Antisense synthesis and purification of c-Met gene. c-Met phosphorothioate oligodexynucleotides (ODNs) corresponding to the human c-Met open reading frame were synthesized using an applied biosystems 3900 DNA synthesizer (Shenggong, Shanghai, China). The antisense and nonsense sequences used were 5'-ACAGCGGGGGCCTTCATTAT-3' and 5'-TC GGCTACAAGCTACGGTTG-3', respectively (9). After the synthesis, ODNs were purified by use of high-pressure liquid chromatography system, dissolved with PBS, and frozen in aliquots at $-20^{\circ} \mathrm{C}$ until use. Prior to use in experiments, these oligonucleotides were diluted with RPMI-1640 medium to the required concentrations.

Preparation of paclitaxel solution. Paclitaxel was obtained from the Division of Cancer Treatment, National Cancer Institute, $\mathrm{NIH}$, as a $6 \mathrm{mg} / \mathrm{ml}(10.5 \mathrm{mM})$ solution in $50 \%$ polyoxyethylated castor oil (Cremphor EL) and 50\% absolute ethanol. Prior to use in experiments, it was diluted with RPMI-1640 medium to the required concentrations.

Incubation of antisense oligodexynucleotides or/and paclitaxel with cells. Cells were incubated on 24-well plate (Corning, USA) at $2 \times 10^{5} / \mathrm{ml}$ per well with $0,50,100,200$ and $400 \mathrm{nmol} / 1$ antisense oligodexynucleotides (ASODNs) and/or $0,1,2,4$ and $8 \mu \mathrm{g} / \mathrm{ml}$ paclitaxel. For controls, the nonsense oligodexynucleotides (NSODNs) were dissolved in RPMI-1640 medium to $50 \mu \mathrm{mol} / 1$. Samples of cells were taken for analysis at various times. Each experiment was performed in triplicate.

Morphological identification of apoptosis and caspase-3 expression in U251 and SHG44 glioma cells by Western blot analysis. The cells were collected and stained with Giemsa at various times after treatment with antisense oligodexynucleotides or/and paclitaxel. Apoptotic changes (blebbing chromosome fragmentation and condensation, and formation of apoptotic bodies) were observed using an Olympus Research microscope. Cells were washed in ice-cold PBS and lysed in a buffer using standard methods. After centrifugation at $10000 \mathrm{~g}$ for $10 \mathrm{~min}$, the supernatants were stored at $-70^{\circ} \mathrm{C}$. Lysate equalized for protein content was separated in $150 \mathrm{~g} / \mathrm{l}$ sodium dodecyl sulfate-polyacrylamide gel electrophoresis and transferred onto a polyvinylidine fluoride membrane. The membranes were blocked for $1 \mathrm{~h}$ at room temperature in $10 \mathrm{~g} / \mathrm{l}$ bovine serum albumin and incubated overnight at $4^{\circ} \mathrm{C}$ with caspase- 3 antibody, followed by incubation with sheep anti-rabbit second antibody conjugated to HRP (Dako,

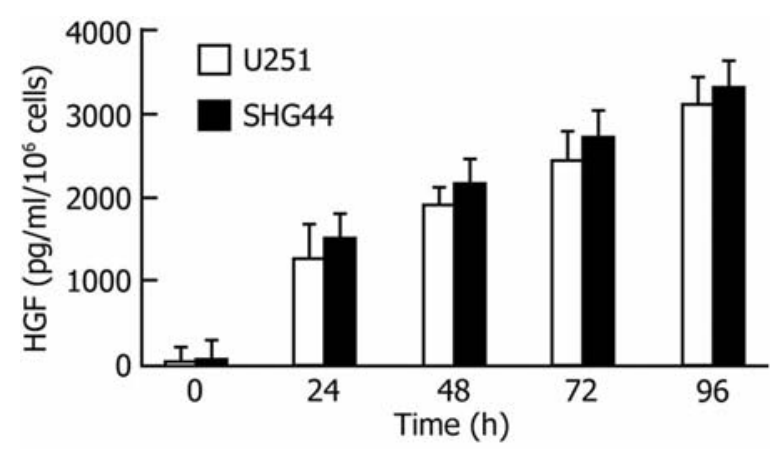

Figure 1. HGF protein levels (pg/ml per $10^{6}$ cells) in U251 and SHG44 glioma cells conditioned medium per day. Mean with SE of 3 separate experiments performed in duplicate are shown. Hepatocyte growth factor secretion by day was calculated from the cumulative data.

Glostrap, Denmark) for 120 min. Finally, the membranes were developed with DAB and incubated until color developed sufficiently.

DNA content analysis by flow cytometry. The cells were collected, washed twice with PBS, and fixed with $70 \%$ alcohol at $4^{\circ} \mathrm{C}$ for $24 \mathrm{~h}$. After two further washings, $200 \mu \mathrm{l}$ of RNAase A $(1 \mathrm{mg} / \mathrm{ml})$ and $800 \mu \mathrm{l}$ of propidium iodide $(100 \mu \mathrm{g} /$ $\mathrm{ml}$ ) were added at $4^{\circ} \mathrm{C}$ for $30 \mathrm{~min}$. DNA content was then analyzed by flow cytometry.

Detection of c-Met protein by flow cytometry. Cells $\left(5 \times 10^{5}\right)$ were collected and fixed with $70 \%$ formaldehyde at $4{ }^{\circ} \mathrm{C}$ for 15 min, then washed and re-suspended twice in specific PBS (s-PBS) (PBS supplemented with 1\% human AB serum, 1\% Tween-20 from Boehringer, Mannheim, $\mathrm{pH}$ 7.2) to permeabilize them. c-Met antibody (Dako) $(50 \mu \mathrm{l})$ was added to the cell suspension and the mixture was incubated at $4^{\circ} \mathrm{C}$ for $1 \mathrm{~h}$. After two further washings with s-PBS, $50 \mu 1$ FITC-IgG (2nd antibody) (Dako) was added and incubated at $4^{\circ} \mathrm{C}$ for $30 \mathrm{~min}$. Finally, the cells were washed twice with PBS and the level of c-Met protein was determined by flow cytometry.

Statistical analysis. All data are expressed as mean \pm SEM. The Kolmogorov-Smirnov test was applied to test for a normal distribution. The means of the different groups were compared by a 1-way ANOVA Student-Newman-Keuls test. SPSS10.0 statistical software was used to analyze the results and $\mathrm{P}<0.05$ was taken as the criterion of significance.

\section{Results}

HGF protein levels, apoptotic morphology and caspase-3 expression in U251 and SHG44 glioma cells by Western blot analysis. The HGF secretion per day increased in U251 and SHG44 cells and the HGF protein levels in SHG44 cells per day were higher than that in U251 cells (Fig. 1). U251 and SHG44 cells treated with various concentration of paclitaxel showed morphological changes characteristic of apoptosis, such as cell shrinkage, chromatin condensation, fragmentation of nuclei and formation of apoptotic bodies (Fig. 2). Expression of caspase- 3 was significantly increased in the U251 and 


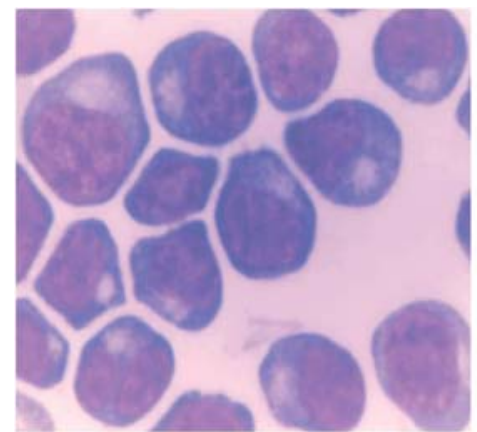

A1

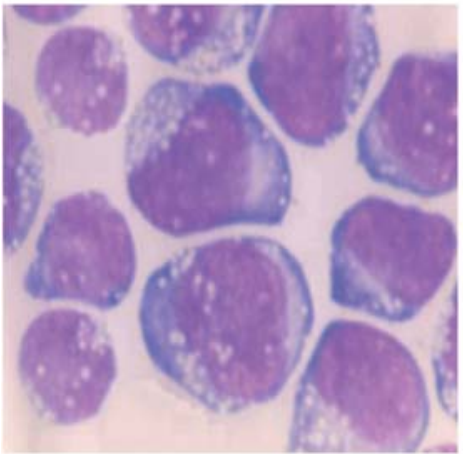

B1

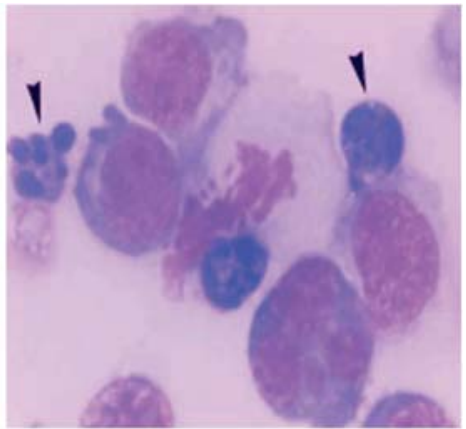

A2

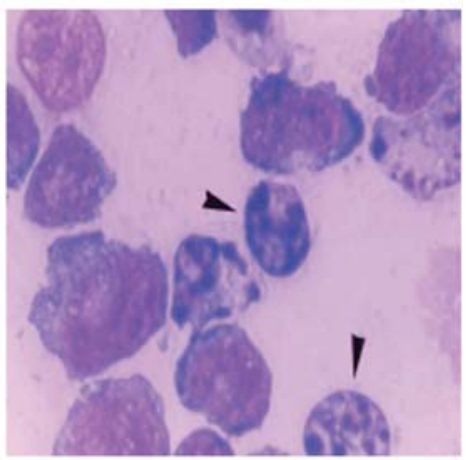

B2

Figure 2. Paclitaxel-induced morphological changes in U251 and SHG44 glioma cells. (A1) Untreated U251 cells (control); (A2) U251 cells treated with $1 \mu \mathrm{g} / \mathrm{ml}$ paclitaxel for $36 \mathrm{~h}$; (B1) Untreated SHG44 cells (control); (B2) SHG44 cells treated with $1 \mu \mathrm{g} / \mathrm{ml}$ paclitaxel for $36 \mathrm{~h}$. The arrows indicate apoptotic cells. Cells were stained with Giemsa (x200).

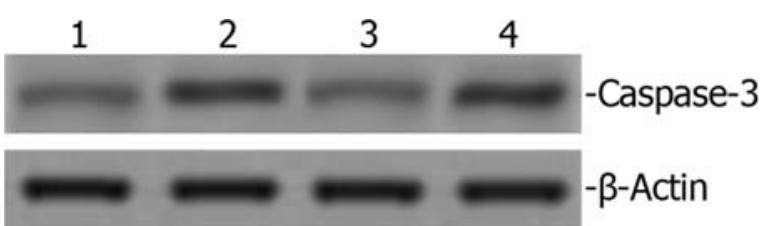

Figure 3. Paclitaxel-induces caspase-3 expression in U251 and SHG44 glioma cells by Western blotting. Lane 1, untreated U251 cells (control); Lane 2, U251 cells treated with $1 \mu \mathrm{g} / \mathrm{ml}$ paclitaxel for $36 \mathrm{~h}$; Lane 3, untreated SHG44 cells (control); Lane 4, SHG44 cells treated with $1 \mu \mathrm{g} / \mathrm{ml}$ paclitaxel for $36 \mathrm{~h}$.

SHG44 glioma cells treated with $1 \mu \mathrm{g} / \mathrm{ml}$ paclitaxel for $36 \mathrm{~h}$ by Western blot analysis (Fig. 3).

Effect of c-Met antisense oligodexynucleotides and paclitaxel on glioma cells. After U251 and SHG44 cells had been treated with various concentrations of c-Met antisense oligodexynucleotides for different times, some cells became apoptotic and growth was inhibited (Fig. 4), when U251 and SHG44 cells were treated with various concentrations of paclitaxel for different times, some cells became apoptotic and growth was inhibited. Fig. 5 shows that U251 cells were more sensitive. Slight but significant inhibition of growth was observed at $0.25 \mu \mathrm{g} / \mathrm{ml}$ paclitaxel, but there was no effect on the growth of SHG44 cells at this concentration. At higher concentrations of paclitaxel $(0.5-2 \mu \mathrm{g} / \mathrm{ml})$, most of the U251 cells were killed but only slight inhibition of SHG44 cells growth was observed at $2 \mu \mathrm{g} / \mathrm{ml}$.

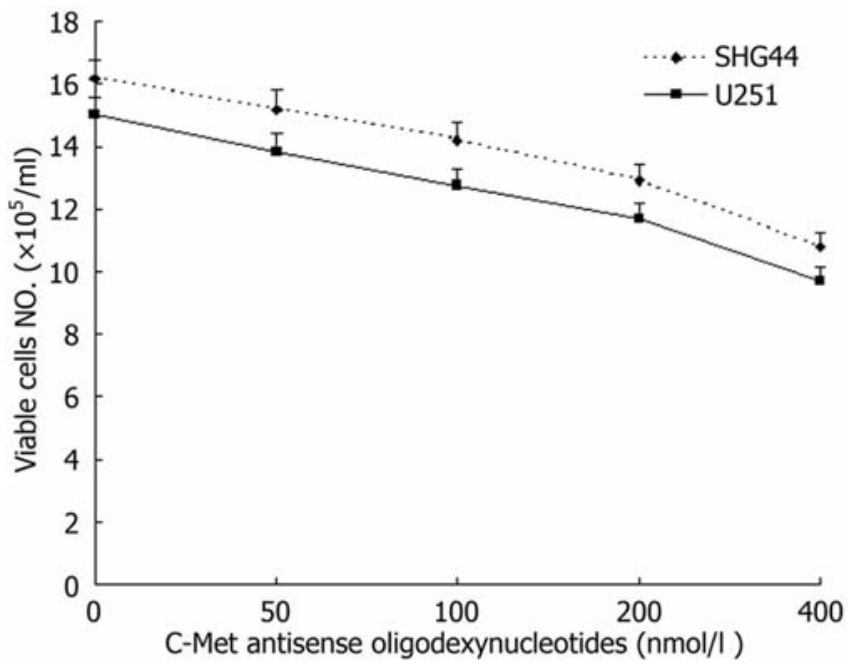

Figure 4. Inhibitory effect of various concentration of c-Met antisense oligodexynucleotides on growth of U251 and SHG44 glioma cells. The cells were incubated $0,50,100,200$ and $400 \mathrm{nmol} / 1 \mathrm{c}-M e t$ antisense oligodexynucleotides for $96 \mathrm{~h}$. Viable cells were counted by the trypan blue exclusion assay. Each point represents the mean of the results from three independent experiments.

Synergistic inhibitory effects of c-Met antisense oligodexynucleotides and paclitaxel on growth of glioma cells. As shown in Fig. 6, ASODNs alone at $100 \mathrm{nmol} / 1 \mathrm{had}$ no significant effect on the growth of U251 cells. However, there was significant inhibition from $24-96 \mathrm{~h}$ when $0.25 \mu \mathrm{g} / \mathrm{ml}$ 


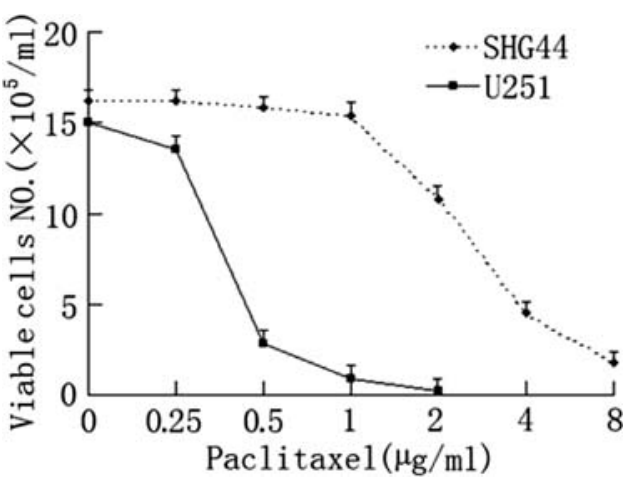

Figure 5. Inhibitory effect of various concentration of paclitaxel on growth of U251 and SHG44 glioma cells. The cells were incubated 0, 0.25, 0.50 , $1.0,2.0,4.0$ and $8.0 \mu \mathrm{g} / \mathrm{ml}$ paclitaxel for $96 \mathrm{~h}$. Viable cells were counted by the trypan blue exclusion assay. Each point represents the mean of the results from three independent experiments. The growth of U251 cells was significantly inhibited by $0.50 \mu \mathrm{g} / \mathrm{ml}$, and that of SHG44 cells by $2.0 \mu \mathrm{g} / \mathrm{ml}$, paclitaxel $(\mathrm{P}<0.05)$.

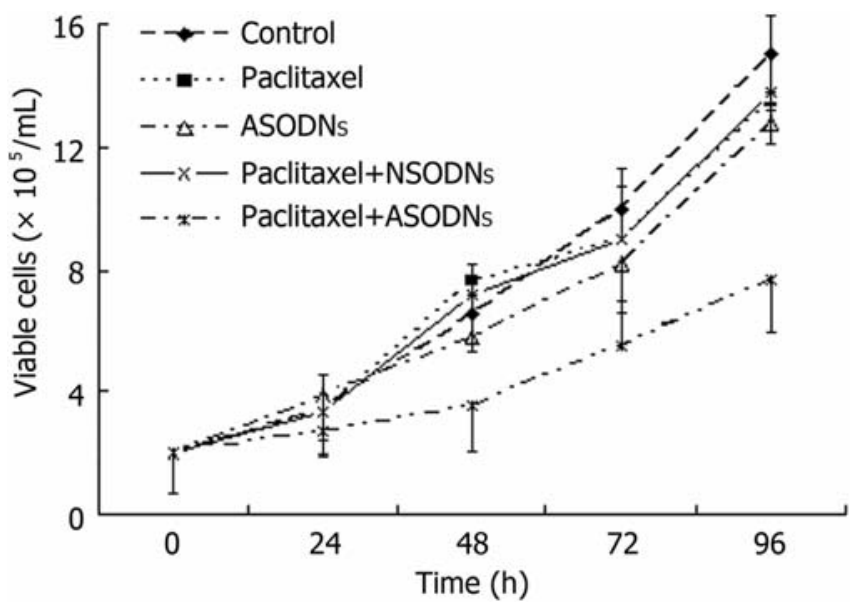

Figure 6. The synergistic inhibitory effects of c-Met antisense oligodexynucleotides and paclitaxel on U251 cell growth. Cells were incubated with paclitaxel $(0.25 \mu \mathrm{g} / \mathrm{ml})$, ASODNs $(100 \mathrm{nmol} / \mathrm{l})$, paclitaxel $(0.25 \mu \mathrm{g} /$ $\mathrm{ml})+\mathrm{NSODNs}(100 \mathrm{nmol} / \mathrm{l})(\mathrm{control})$, or paclitaxel $(0.25 \mu \mathrm{g} / \mathrm{ml})+$ ASODNs (10 nmol/1) for $24,48,72$ and $96 \mathrm{~h}$. The growth of U251 cells treated with paclitaxel and ASODNs in combination was significantly inhibited compared with the control and other groups between 24 and $96 \mathrm{~h}(\mathrm{P}<0.05$ or 0.01$)$.

paclitaxel and $100 \mathrm{nmol} / \mathrm{l}$ of ASODNs were used in combination, and this inhibition grew more marked at longer incubation times. At $96 \mathrm{~h}$, the survival rate of U251 cells was about half of that observed when ASODNs or paclitaxel were used alone. As shown in Fig. 7, similarly, in SHG44 cells, $100 \mathrm{nmol} / 1 \mathrm{ASODNs}$ had no significant effect on growth, but there was significant inhibition from 24 to $96 \mathrm{~h}$ when $2.0 \mu \mathrm{g} / \mathrm{ml}$ paclitaxel and $100 \mathrm{nmol} / \mathrm{l}$ ASODNs were used in combination. Again, this inhibition became more marked at longer incubation times, and at $96 \mathrm{~h}$ the survival rate of SHG44 cells was about half of that observed with ASODNs or paclitaxel alone.

c-Met antisense oligodexynucleotides increase the susceptibility of glioma cells to paclitaxel-induced apoptosis. As shown in Fig. 8, 35.75 \pm 4.2 of U251 cells and 37.25 \pm 5.9 of

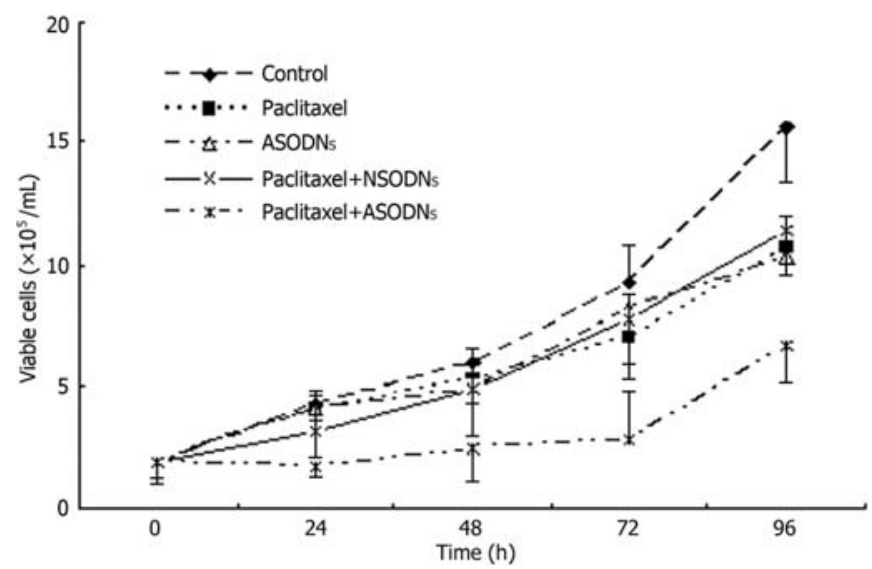

Figure 7. The synergistic inhibitory effect of c-Met antisense oligodexynucleotides and paclitaxel on SHG44 cell growth. Cells were incubated with paclitaxel $(2.0 \mu \mathrm{g} / \mathrm{ml})$, ASODN $(100 \mathrm{nmol} / \mathrm{l})$, paclitaxel $(2.0 \mu \mathrm{g} / \mathrm{ml})+$ SODNs (100 nmol/l) (control), or paclitaxel $(2.0 \mu \mathrm{g} / \mathrm{ml})+$ ASODNs (100 $\mathrm{nmol} / \mathrm{l})$ for $24,48,72$ and $96 \mathrm{~h}$. The growth of SHG44 cells treated with paclitaxel and ASODNs in combination was significantly inhibited compared with the control and other groups between 24 and $96 \mathrm{~h}(\mathrm{P}<0.05$ or $0.01)$.

SHG44 cells became apoptotic when paclitaxel and ASODNs were used in combination. When paclitaxel or ASODNs were used alone, the equivalent percentages were 5.23 \pm 1.7 and $15.23 \pm 3.9$ for $\mathrm{U} 251$ cells and $14.34 \pm 3.4$ and $10.65 \pm 3.4$ for SHG44 cells. The control nonsense oligodexynucleotides (NSODNs), unlike ASODNs, did not affect the susceptibilities of the glioma cells to paclitaxel.

Effect of c-Met antisense oligodexynucleotides in combination with paclitaxel on $\mathrm{c}$-Met protein expression. As shown in Fig. 9, the percentages of c-Met protein expressed in U251 and SHG44 cells (U251, 25.98 \pm 3.96 ; and SHG44, 20.15 \pm 5.82 ) were significantly lower when paclitaxel and ASODNs were used in combination than when either was used singly.

\section{Discussion}

Our previous studies showed c-Met ASODNs could downregulate or inhibit c-Met mRNA and protein in U251, which could inhibit U251 glioma cells growth and induce cell apoptosis (9). The results described in this report show that low doses of paclitaxel (up to $0.25 \mu \mathrm{g} / \mathrm{ml}$ for U251 and $2.0 \mu \mathrm{g}$ / $\mathrm{ml}$ for SHG44) do not affect glioma cell growth significantly (Fig. 1). However, the susceptibility of glioma cells to paclitaxel is greatly increased by c-Met antisense oligodexynucleotides. Along with c-Met amplification, the results indicate c-Met mutation is unlikely. Under the combined treatment, cell growth was inhibited, a large number of glioma cells died, and expression of the c-Met gene was significantly decreased (Figs. 3, 5, 6 and 7). Even though paclitaxel treatment was associated with the activation of the survival kinase Akt and an anti-apoptotic expression of cytoplasmic p21WAF and cyclin D1, this inhibition of cell death was abrogated by depletion of transforming acidic coiled coil 3 (16). The pharmacological effect of paclitaxel is therefore strengthened by c-Met antisense oligodexynucleotides. Based on the results and analysis, paclitaxel appears to 


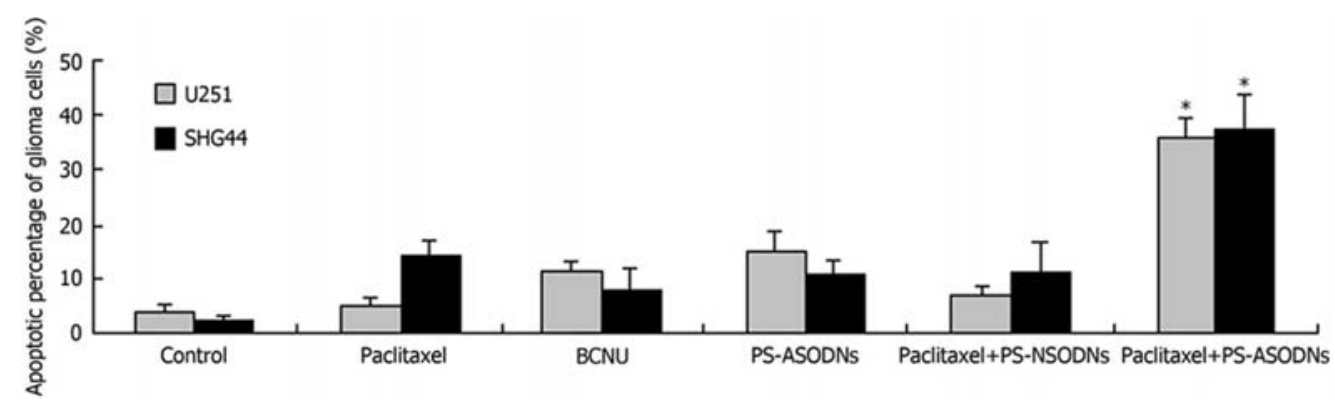

Figure 8. Apoptotic percentage of glioma cells treated with paclitaxel in combination with c-Met antisense oligodexynucleotides. The cells were incubated for $96 \mathrm{~h}$ with paclitaxel (U251, $0.25 \mu \mathrm{mol} / 1$; SHG44, $2.0 \mu \mathrm{mol} / \mathrm{l})$, positive control BCNU $(0.01 \mu \mathrm{mol} / 1)$, PS-ASODNs $(100 \mathrm{nmol} / \mathrm{l})$, paclitaxel + PS-NSODNs, or paclitaxel + PS-ASODNs, and then stained with propidium iodide. The apoptotic cell counts were determined by flow cytometry. Each value in the figure is the mean of triplicate experiments. The means of the different groups were compared by a 1-way ANOVA Student-Newman-Keuls test. "P<0.05 compared with others.

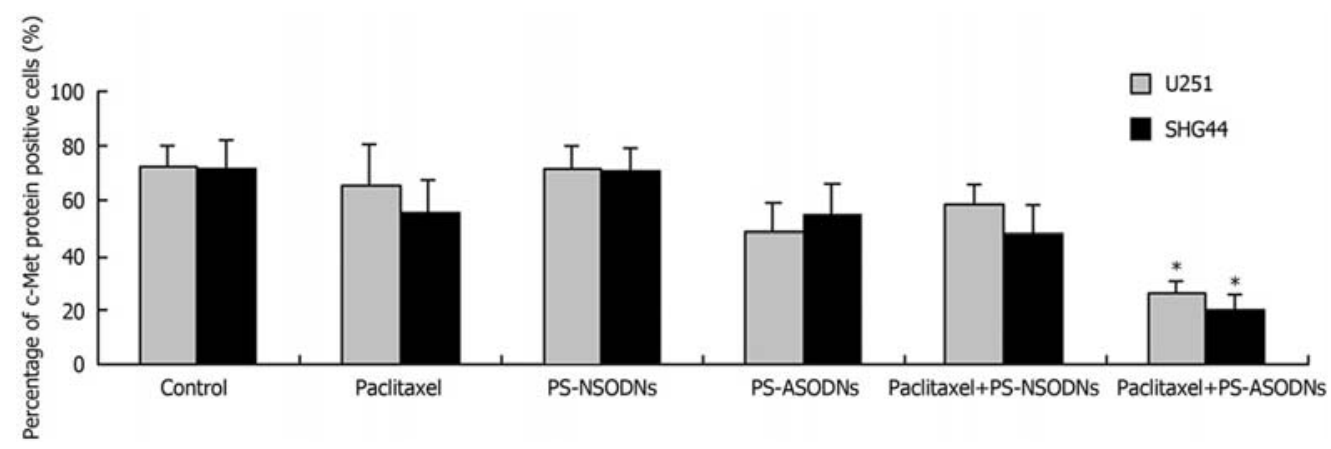

Figure 9. Percentage of c-Met protein positive cells determined by flow cytometry. The cells were incubated for $96 \mathrm{~h}$ with paclitaxel (U251, $0.25 \mu \mathrm{mol} / \mathrm{l}$; SHG44, $2.0 \mu \mathrm{mol} / \mathrm{l})$, PS-ASODNs (100 nmol/l), paclitaxel + PS-NSODNs, or paclitaxel + PS-ASODNs. The percentage of c-Met protein positive cells is significantly lower after paclitaxel + PS-ASODNs than other treatments, as shown by immuno-tissue chemistry and flow cytometry. Each value in the figure is the mean of triplicate experiments. ${ }^{*} \mathrm{P}<0.05$ compared with others.

induce apoptotic effect in glioma cells by down-regulating the c-Met gene expression, blocking cells into $\mathrm{S}$ phrase and inhibiting DNA synthesis inhibition and microtubule polymerization (17-19). Genetic etiology of glioma is not entirely clear and glioma is inclined to be caused by multiple genetic abnormalities. Although both U251 and SHG44 have high levels of c-Met expression, they differ markedly in their susceptibility to paclitaxel, as shown in Fig. 2. The percentage of c-Met protein positive cells is, respectively $(72.04 \pm 8.2) \%$ and $(71.72 \pm 10.8) \%$ in U251 and SHG44 glioma cells. The cells were incubated for $96 \mathrm{~h}$ with PS-ASODNs (100 nmol/l), The percentage of c-Met protein positive cells is, respectively $(48.56 \pm 10.2) \%$ and $(54.62 \pm 13.4) \%$ in $\mathrm{U} 251$ and SHG44 glioma cells (Fig. 8). The reduction of Met protein with a treatment of $100 \mathrm{nmol} / \mathrm{l} \mathrm{ASODN}$ is, respectively about 33 and $24 \%$. The reason for this difference in susceptibility is unclear at present and likely to be related to the difference in HGF protein levels of U251 and SHG44 glioma cells conditioned medium per day. A single factor in the complete role in the process of glioma is not clear, thorough interpretation of the gene 'Password' of glioma still needs a more comprehensive, in-depth study (20). The cytotoxic effects of paclitaxel are complex and involve many genes, c-myc, p53 and $\mathrm{BCR} / \mathrm{ABL}$ genes contribute to the apoptotic processes induced by paclitaxel (21-23). However, the c-Met gene is prominent in regulating U251 glioma cells growth and apoptosis, and we have previously found HGF to decrease the susceptibility of human U251 glioma cells to chemotherapeutic drug mitomycin $\mathrm{C}$, c-Met antisense oligodexynucleotides are known to increase the susceptibility of human U251 glioma cells to chemotherapeutic drug mitomycin C $(9,14,15)$. The results found in this study are consistent with this view.

Antisense oligonucleotide and the drug directly injected into brain with high-flow microinfusion can be safely delivered at high concentration to wide areas of rat brain, bypassing the blood-brain barrier and avoiding the implications after systemic administration $(24,25)$. Clinical trials of this drug in humans have been discouraging $(26,27)$. This might be because of the in vivo resistance of human astrocytoma. Our results described herein show that c-Met antisense oligodeoxynucleotides increase the sensitivity of human glioma cells to paclitaxel. This study illustrates how attacking the basic cellular and molecular mechanisms that contribute to malignant cell proliferation (such as targeting the c-Met oncogene) can potentially lead to inhibition of glioma cell growth. Perhaps, in future work, newer methods of blocking c-Met expression (such as with siRNA/shRNA technology) and the drug paclitaxel combined with direct intraparenchymal convection enhanced microinfusion will be able to 
demonstrate an effect of such targeted gene strategies for gliomas in vivo. Otherwise, it is meaningful to test further whether ASODNs targeting c-Met can enhance the sensitivity of a more clinically applicable drug, such as BCNU or temozolomide.

\section{Acknowledgements}

This study was partially supported by a grant from the Natural Science Foundation of China (30901535), a grant (2008Y066) from the Shanghai Municipal Health Bureau Youth Projects, a grant (07JWYQ03) from the Training Excellent Youth Teacher Scientific Research Foundation of University of Shanghai, and a grant (07XYQ01) from the Excellent Youth Teacher Scientific Research Foundation of Shanghai Jiao Tong University of School of Medicine.

\section{References}

1. Giannopoulos T, Butler-Manuel S, Taylor A, Ngeh N and Thomas H: Clinical outcomes of neoadjuvant chemotherapy and primary debulking surgery in advanced ovarian carcinoma. Eur J Gynaecol Oncol 27: 25-28, 2006.

2. Petrek JA, Naughton MJ, Case LD, Paskett ED, Naftalis EZ, Singletary SE and Sukumvanich P: Incidence, time course, and determinants of menstrual bleeding after breast cancer treatment: a prospective study. J Clin Oncol 24: 1045-1051, 2006.

3. Paccagnella A, Oniga F, Bearz A, et al: Adding gemcitabine to paclitaxel/carboplatin combination increases survival in advanced non-small cell lung cancer: results of a phase II-III study. J Clin Oncol 24: 681-687, 2006.

4. Schmidt M, Schler G, Gruensfelder P, Favaretto A, Clerici M, Barbieri F, Riccardi A, Chella A, Tirelli U, Ceresoli G, Tumolo S, Ridolfi R, Biason R, Nicoletto MO, Belloni P, Veglia F and Ghi MG: Differential gene expression in a paclitaxel-resistant clone of a head and neck cancer cell line. Eur Arch Otorhinolaryngol 263: 127-134, 2006.

5. Li PK, Pandit B, Sackett DL and Hoppe F: A thalidomide analogue with in vitro antiproliferative, antimitotic and microtubule-stabilizing activities. Mol Cancer Ther 5: 450-456, 2006.

6. Tabata H: Paclitaxel production by plant-cell-culture technology. Adv Biochem Eng Biotechnol 87: 1-23, 2004.

7. Yoshiike F, Koizumi T, Kitaguchi Y, Hatayama O, Yasuo M, Sasabayashi M, Wakamatsu H, Fujimoto K and Kubo K: Phase I trial of nedaplatin and paclitaxel for patients with non-small cell lung cancer. J Chemother 17: 550-554, 2005.

8. Chu SH, Yuan XH, Jiang PC, Li ZQ, Zhang J, Wen ZH, Zhao SY, Chen XJ and Cao CJ: The expression of hepatocyte growth factor and its receptor in brain astrocytomas. Zhonghua Yi Xue Za Zhi 85: 835-838, 2005.

9. Chu SH, Yuan XH, Li ZQ, Jiang P and Zhang J: C-Met antisense oligodeoxynucleotide inhibits growth of glioma cells Surg Neurol 65: 533-538, 2006.

10. Chu SH, Zhang H, Ma YB, Feng DF, Zhu ZA, Yuan XH and Li ZQ: C-Met antisense oligodeoxynucleotides as a novel therapeutic agent for glioma: in vitro and in vivo studies of uptake, effects and toxicity. J Surg Res 141: 284-288, 2007.

11. Chu SH, Zhu ZA, Yuan XH, Feng DF, Zhu ZA, Yuan XH and Li ZQ: In vitro and in vivo potentiating the cytotoxic effect of radiation on human $\mathrm{U} 251$ gliomas by the c-Met antisense oligodeoxynucleotides. J Neurooncol 80: 143-149, 2006.
12. Chu SH, Ma YB, Zhang H, Feng DF, Zhu ZA, Li ZQ and Yuan XH: Hepatocyte growth factor production is stimulated by gangliosides and TGF-beta isoforms in human glioma cells. J Neurooncol 85: 33-38, 2007.

13. Chu SH, Ma YB, Zhu ZA, Zhang H, Feng DF, Li ZQ and Yuan XH: Radiation-enhanced hepatocyte growth factor secretion in malignant glioma cell lines. Surg Neurol 68: 610$613,2007$.

14. Chu SH, Yuan XH and Jiang PC: Recombinant human hepatocyte growth factor in cellular apoptosis of glioma induced by mitomycin C. Chin J Neuromed 4: 1093-1096, 2005.

15. Jiang PC, Chu SH and Yuan XH: The c-met protooncogene antisense oligodeoxynucleotide enhances the sensitivity of glioma cell U251 to mitomycin C. Chin J Exp Surg 23: 540-542, 2006.

16. Schneider L, Essmann F, Kletke A, Rio P, Hanenberg H, Schulze-Osthoff K, Nürnberg B and Piekorz RP: TACC3 depletion sensitizes to paclitaxel-induced cell death and overrides $\mathrm{p} 21^{\mathrm{WAF}}$-mediated cell cycle arrest. Oncogene 27: 116-125, 2008.

17. Terzis AJ, Thorsen F, Heese O, Visted T, Bjerkvig R, Dahl O, Arnold $\mathrm{H}$ and Gundersen G: Proliferation, migration and invasion of human glioma cells exposed to paclitaxel (Taxol) in vitro. $\mathrm{Br}$ J Cancer 75: 1744-1752, 1997.

18. Fueyo J, Gomez-Manzano C, Puduvalli VK, Martin-Duque P, Perez-Soler R, Levin VA, Yung WK and Kyritsis AP: Adenovirus-mediated p16 transfer to glioma cells induces G1 arrest and protects from paclitaxel and topotecan: implications for therapy. Int J Oncol 12: 665-669, 1998.

19. Chung WH, Sung BH, Kim SS, Rhim H and Kuh HJ: Synergistic interaction between tetra-arsenic oxide and paclitaxel in human cancer cells in vitro. Int J Oncol 34: 16691679, 2009.

20. Li JJ and Zhao JZ: Comparison between the expression of apotosis-related factor of BT325 human glioblastoma and U251 glioblastoma. J Cap Med Univ 29: 45-48, 2008.

21. Cassinelli G, Supino R, Zuco V, Lanzi C, Scovassi AI, Semple SC and Zunino F: Role of c-myc protein in hormone refractory prostate carcinoma: cellular response to paclitaxel. Biochem Pharmacol 68: 923-931, 2004

22. Ray S, Lu Y, Kaufmann SH, et al: Genomic mechanisms of p210BCR-ABL signaling: induction of heat shock protein 70 through the GATA response element confers resistance to paclitaxel-induced apoptosis. J Biol Chem 279: 35604-35615, 2004.

23. Cui W, Wu R, Cao H, Gustafson WC, Karp JE, Boldogh I, Fields AP and Brasier AR: P53 gene mutation and expression of MDM2, P53, P16 protein and their relationship in human glioma. J Huazhong Univ Sci Technolog Med Sci 25: 622-624, 2005.

24. Broaddus WC, Prabhu SS, Gillies GT, Neal J, Conrad WS, Chen ZJ, Fillmore H and Young HF: Distribution and stability of antisense phosphorothioate oligonucleotides in rodent brain following direct intraparenchymal controlled-rate infusion. J Neurosurg 88: 734-742, 1998.

25. Laske DW, Youle RJ and Oldfield EH: Tumor regression with regional distribution of the targeted toxin TF-CRM107 in patients with malignant brain tumors. Nat Med 3: 1362-1368, 1997.

26. Prados MD, Schold SC, Spence AM, Berger MS, McAllister LD, Mehta MP, Gilbert MR, Fulton D, Kuhn J, Lamborn K, Rector DJ and Chang SM: Phase II study of paclitaxel in patients with recurrent malignant glioma. J Clin Oncol 14: 2316-2321, 1996.

27. Tishler RB, Geard CR, Hall EJ and Schiff PB: Taxol sensitizes human astrocytoma cells to radiation. Cancer Res 52: 3495-3497, 1992. 